\title{
Immunogenicity Test of Tetanus Component in Adsorbed Vaccines by Toxin Binding Inhibition Test
}

\author{
Denise Cristina Souza Matos/ ${ }^{++}$, Rugimar Marcovistz $/^{+}$, Pedro Hernan Cabello*, \\ Ricardo Amaral Georgini, Dirce Sakauchi, Luciana Leite da Silva
}

\author{
Serviço de Controle de Qualidade, Instituto Butantan, Av. Vital Brasil 1500, 05503-900 São Paulo, SP, Brasil \\ *Departamento de Genética, Instituto Oswaldo Cruz-Fiocruz, Rio de Janeiro, RJ, Brasil
}

\begin{abstract}
Samples from 20 lots of diphtheria-tetanus (adult use dT) vaccine and from 20 lots of diphtheria-tetanuspertussis (DTP) vaccine were used to standardize and validate the in vitro toxin binding inhibition (ToBI) test for the immunogenicity test of the tetanus component. The levels of tetanus antitoxin obtained by ToBI test were compared to those obtained using the toxin neutralization (TN) test in mice routinely employed to perform the quality control of the tetanus component in adsorbed vaccines. The results ranged from 1.8 to $3.5 \mathrm{IU} / \mathrm{ml}$ for $d T$ and 2 to $4 \mathrm{IU} /$ $\mathrm{ml}$ for DTP by ToBI test and 1.4 to $3 \mathrm{IU} / \mathrm{ml}$ for $d T$ and 1.8 to $3.5 \mathrm{IU} / \mathrm{ml}$ for DTP by TN in mice. These results were significantly correlated. From this study, it is concluded that the ToBI test is an alternative to the in vivo neutralization procedure in the immunogenicity test of the tetanus component in adsorbed vaccines. A substantial refinement and a reduction in use of animals can be achieved.
\end{abstract}

Key words: diphtheria-tetanus vaccine - diphtheria-tetanus-pertussis vaccine - toxin binding inhibition test - tetanus quality control - seroneutralization

In the last decade, a big effort has been made to attempt replacement and reduction of animals in the development and control of biological products, mobilizing research scientists, manufacturers and regulators such as World Health Organization (WHO 1995, Sesardic \& Hendriksen 1999). Besides ethical reasons, the replacement of challenge tests in animals by in vitro tests to control of biological products presents an additional impact for developing countries, as it is difficult to obtain quality of laboratory animals and adequate environmental conditions. Therefore, several in vitro serological assays for titration of tetanus antitoxin have been developed, such as, passive and indirect haemagglutination (Peel 1980, Gupta et al. 1984, Huet et al. 1992), several versions of enzymatic linked immunosorbent assay (ELISA) (Melville-Smith et al. 1983, Gentili et al. 1985, Simonsen et al. 1987, Esparza \& Kissel 1992, Gupta \& Siber 1994) and the toxin binding inhibition (ToBI) test (Hendriksen et al. 1988, 1989a). In this later test, the seroneutralization is followed by an ELISA which detects the free toxin into the toxin-serum mixtures. The ToBI test was first developed for determining antitoxin titres to tetanus in human sera (Hendriksen et al. 1988). Recently, it has also been proposed as an alternative assay to the in vivo challenge test for the potency control of tetanus toxoid vaccines (Hendriksen et al. 1991, WHO 1995).

Financial support: Fapesp Proc. no. 97/11707-3

${ }^{+}$Corresponding author. Present address: Departamento de Desenvolvimento Tecnológico, Bio-Manguinhos-Fiocruz, Av. Brasil 4365, 21045-900 Rio de Janeiro, RJ, Brasil.

Fax: +55-21-2260.4727. E-mail: rugimar@bio.fiocruz.br

${ }^{++} \mathrm{CNPq}$ fellowship

Received 3 November 2001

Accepted 21 March 2002
In the present report, we describe the standardization and validation of the ToBI test to control the immunogenicity of the tetanus component in diphtheria-tetanus (adult use dT) and diphtheria-tetanus-pertussis (DTP) vaccines produced in our Institute. This control is routinely performed by a toxin neutralization (TN) test in mice according to the Minimum Requirement of Production and Control from the Brazilian Ministery of Health (Secretaria de Vigilância Sanitária 1998, Farmacopéia Brasileira 2000).

\section{MATERIALS AND METHODS}

Animals - Following the methodologies described by the Secretaria de Vigilância Sanitária (1998), guinea pigs weighing 450-550 $\mathrm{g}$ for immunization and BALB/c mice weighing 18-20 g for the TN test were obtained from the Butantan Institute Facilities, São Paulo, Brazil.

Vaccines - Twenty licensed lots of dT vaccine containing $4 \mathrm{Lf} / \mathrm{ml}$ of diphtheria toxoid, $15 \mathrm{Lf} / \mathrm{ml}$ of tetanus toxoid and 20 licensed lots of DTP vaccine containing 15 $\mathrm{Lf} / \mathrm{ml}$ of diphtheria toxoid, $15 \mathrm{Lf} / \mathrm{ml}$ of tetanus toxoid and $32 \mathrm{OU} / \mathrm{ml}$ of whole cell of Bordetella pertussis, adsorbed onto $0.5 \mathrm{mg} / \mathrm{ml}$ of aluminum hydroxide routinely produced by Division of Bacterial Products at Butantan Institute, were used to immunized the animals.

Standard tetanus toxin, anatoxin and antitoxin Tetanus toxin $(1,000 \mathrm{Lf} / \mathrm{ml})$ and anatoxin $(1,520 \mathrm{Lf} / \mathrm{ml})$, prepared in the Bacterial Vaccine Section at the Butantan Institute, was used for the in vivo $\mathrm{TN}$ test and for the ToBI test, respectively. Standard tetanus antitoxin $(1,000$ IU/vial) was obtained from the National Health Control Authority (INCQS-Fiocruz, Rio de Janeiro, Brazil) and diluted at $10 \mathrm{UI} / \mathrm{ml}$ in PBS with $50 \%$ of glycerol was stored at $-20^{\circ} \mathrm{C}$.

Immunization of guinea pigs - Six guinea pigs were injected subcutaneously with half of the immunizing dose used for vaccinating human $(0.75 \mathrm{ml})$. After six weeks the 
animals were bled by cardiac puncture and the sera were inactivated $\left(56^{\circ} \mathrm{C} / 30 \mathrm{~min}\right)$ and stored at $-20^{\circ} \mathrm{C}$.

In vivo TN test - This test was carried out according to the Brazilian Ministery of Health (Secretaria de Vigilância Sanitária 1998). The serum pool, from at least four immunized guinea pigs, was prepared by mixing equal volumes of each collected serum. The antitoxin titre was determined by mixing $1 \mathrm{ml}$ of each serum pool, diluting the serum pool to a $\mathrm{L}+/ 10 / 50$ dose of tetanus toxin defined as a dose of toxin in $1 \mathrm{ml}$ of PBS able to neutralize $0.1 \mathrm{IU}$ of standard antitoxin, killing mice with 18-20 g within $96 \mathrm{~h}$. After incubation at $37^{\circ} \mathrm{C}$ for $45 \mathrm{~min}, 0.75 \mathrm{ml}$ of the mixture was subcutaneously injected in 10 normal mice. A control test with a mixture containing the toxin $(\mathrm{L}+/ 10 / 50)$ and three dilutions of the standard antitoxin were tested in parallel, also using 10 mice per dilution. The animals were observed for four days for tetanus symptoms and deaths. The lethal dose 50 (LD50) value of the tested sample was determined by Probit analysis. The potency of the tetanus component was calculated by $\mathrm{A} / \mathrm{BxC}$, where $\mathrm{A}$ was the effective dose 50 (ED50) of standard tetanus antitoxin, B was the LD50 of tested serum and C the IU/ml of standard tetanus antitoxin.

ToBI test - This test was performed as described by Hendriksen et al. (1989a) by employing tetanus anatoxin instead of tetanus toxin.

Peroxidase-labeled antitetanus $\operatorname{Ig} G F\left(a b^{\prime}\right)_{2}$ - Purified antitetanus $\mathrm{F}(\mathrm{ab})_{2}$ fragments were prepared by enzymatic digestion from hyperimmunized horse serum in the Technological Development and Production Division at the Butantan Institute. The conjugate peroxidase-glutaraldehyde- $\mathrm{F}\left(\mathrm{ab}{ }^{\prime}\right)_{2}$ was prepared as described by Avrameas and Ternynck (1971). The produced conjugate, at a 1:2000 dilution, was able to detect $0.062 \mathrm{Lf} / \mathrm{ml}$ of tetanus anatoxin.

Guinea pig serum pool dilutions - A round-bottom polystyrene microplate was blocked with $200 \mu \mathrm{l} /$ well of skimmed milk at $1 \%$ during $90 \mathrm{~min}$ at $37^{\circ} \mathrm{C}$. After blocking, the microplate was washed with buffer A (saline $\mathrm{pH} 7.2$ and $0.05 \%$ of Tween-80) and dried. The serum pool samples were diluted in PBS from 1:2 to 1:1024 in a volume of $100 \mu \mathrm{l}$ in duplicate. In parallel, a curve of standard tetanus antitoxin was made to plot the results of unknown serum samples. The standard antitoxin was diluted from 10 to $0.156 \mathrm{IU} / \mathrm{ml}$ in two horizontal columns with $100 \mu \mathrm{l} /$ well. A volume of $100 \mu \mathrm{l}$ of tetanus anatoxin $(1 \mathrm{Lf} / \mathrm{ml})$ was added in all wells. The positive control was made in an horizontal column with anatoxin and PBS (100\% absorbance) and the negative control in the subsequent column with PBS only. The microplate was incubated during $60 \mathrm{~min}$ at $37^{\circ} \mathrm{C}$ and then overnight at $4^{\circ} \mathrm{C}$.

Coated plate for ELISA assay - A microplate of polyvinyl chloride for immunoassay was coated with $100 \mu \mathrm{l}$ of carbonate buffer $\mathrm{pH} 9.6$ containing $20 \mu \mathrm{g} / \mathrm{ml}$ of $\mathrm{F}\left(\mathrm{ab}^{\prime}\right)_{2}$ of antitetanus $\operatorname{IgG~F}\left(\mathrm{ab}^{\prime}\right)_{2}$ fragments. After incubation overnight at $4^{\circ} \mathrm{C}$, the microplate was washed three times with buffer $A$ and blocked with $200 \mu$ l of skimmed milk at $1 \%$ in PBS pH 7.2 during 60 min at room temperature and then washed and dried. One hundred microliters of the serumanatoxin mixtures were transferred to each corresponding well of coated microplate and incubated for $90 \mathrm{~min}$ at $37^{\circ} \mathrm{C}$.
After three washings with buffer A and drying, $100 \mu$ l of the diluted peroxidase-conjugate $(1: 2000)$ in PBS were then added in all wells and the microplate incubated again for $60 \mathrm{~min}$ at room temperature in the dark. After three washings with buffer A, $100 \mu$ l of the substrate $(1.7 \%$ of $25 \mathrm{mM}$ Tetramethyl-Benzidine, $0.03 \%$ of $\mathrm{H}_{2} \mathrm{O}_{2}$ in $11 \mathrm{mM}$ sodium acetate buffer, $\mathrm{pH}$ 5.5) was added as described by Hendriksen et al. (1989a). After $15 \mathrm{~min}$ in dark, the reaction was stopped by the addition of $2 \mathrm{M} \mathrm{H}_{2} \mathrm{SO}_{4}$. The absorbance was measured at $450 \mathrm{~nm}$ using a Multiskan EX/ Labsystem automatic plate reader. The maximum absorbance $\left(\mathrm{Ab}_{100}\right)$ were obtained from the wells with standard anatoxin only. These values were equal to 1.6 with a standard deviation of \pm 0.005 . The $A b_{50}$ was determined as half of the $A b_{100}$ average, corresponding thus to wells with approximately $50 \%$ of neutralized anatoxin. The serum samples which values were near to $\mathrm{Ab}_{50}$ were plotted in a standard antitoxin curve. The antitoxin titre of tested serum pools was calculated by the $A b_{50}$ value multiplied by the inverse of the corresponding dilution and expressed in IU $/ \mathrm{ml}$. The calculation was made using the software Multicont (Multiskan Transmit Software revision 4.5).

Statistical analysis - The Kruskal-Wallis nonparametric tests were employed to evaluate the homogeneity among the repetitions of tests per lot of vaccines and among the results of lots. The Spearman's correlation coefficient was used to compare the relationship between the ToBI test and the in vivo TN test. Statistical analysis were performed using the Statistical Package of Social Sciences software (1997).

\section{RESULTS}

ToBI test was employed to determine the levels of tetanus antitoxin in pooled sera from guinea pigs immunized with different lots of dT and DTP vaccines. These results were compared to the in vivo TN test used routinely to perform the potency test of tetanus component in adsorbed vaccines.

Fig. 1 represents the standard curve of the standard tetanus antitoxin, ranging from 0.156 to $10 \mathrm{IU} / \mathrm{ml}$ and mixed with $1 \mathrm{Lf} / \mathrm{ml}$ of tetanus anatoxin. The lowest concentration of tetanus antitoxin able to neutralize $1 \mathrm{Lf} / \mathrm{ml}$ of anatoxin was $0.156 \mathrm{IU} / \mathrm{ml}$ in the ToBI test.

Tables I and II show the potency results of the tetanus component of different lots of dT and DTP vaccines obtained by ToBI and in vivo neutralization tests. The titre values were ranged from 1.8 to $3.5 \mathrm{IU} / \mathrm{ml}$ for $\mathrm{dT}$ and 2 to $4 \mathrm{IU} / \mathrm{ml}$ for DTP by ToBI test and 1.4 to $3 \mathrm{IU} / \mathrm{ml}$ for dT and 1.8 to $3.5 \mathrm{IU} / \mathrm{ml}$ for DTP by TN test in mice. The ToBI/ in vivo ratio of mean titre was $1.24( \pm 0.096)$ for $\mathrm{dT}$ and $1.14( \pm 0.07)$ for DTP. The statistical analysis applied to evaluate the reproducibility of the results did not detect significant difference in seven and three separate experiments of in vitro and in vivo tests, respectively, for all lots of dT or DTP analyzed. The results obtained by ToBI test presented a high homogeneity according to the KruskalWallis test for each lot of dT and DTP vaccines analyzed with $\mathrm{H}=1.367(\mathrm{p}=0.968)$ and $\mathrm{H}=0.487(\mathrm{p}=0.998)$, respectively. Similar results was also found for the in vivo neutralization test for the same lots evaluated with $\mathrm{H}=0.232$ 


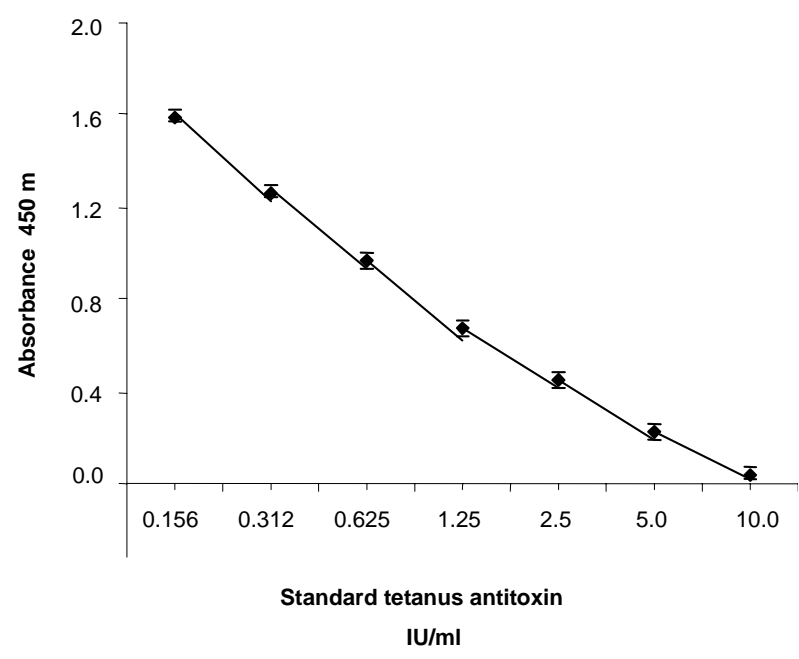

Fig. 1: different concentrations of standard tetanus antitoxin were mixed with $1 \mathrm{Lf} / \mathrm{ml}$ of tetanus anatoxin. The results were plotted as mean with bars indicating \pm SD from 20 independent tests.

TABLE I

Tetanus component potency of diphtheria-tetanus vaccine by in vitro and in vivo neutralization tests

\begin{tabular}{lccc}
\hline Vaccine & \multicolumn{2}{c}{$\begin{array}{c}\text { Tetanus antitoxin } \\
(\mathrm{IU} / \mathrm{ml})\end{array}$} & $\begin{array}{c}\text { Ratio } \\
\text { in vitro/in vivo }\end{array}$ \\
\cline { 2 - 4 } Lots & ToBI & L $+/ 10 / 50$ & ToBI/in vivo \\
\hline $\mathrm{A}$ & $2.30( \pm 0.1)$ & $1.80( \pm 0.1)$ & 1.28 \\
$\mathrm{~B}$ & $2.50( \pm 0.3)$ & $2.25( \pm 0.2)$ & 1.11 \\
$\mathrm{C}$ & $3.00( \pm 0.4)$ & $2.60( \pm 0.1)$ & 1.15 \\
$\mathrm{D}$ & $2.00( \pm 0.2)$ & $1.80( \pm 0.4)$ & 1.11 \\
$\mathrm{E}$ & $3.50( \pm 0.2)$ & $3.00( \pm 0.1)$ & 1.17 \\
$\mathrm{~F}$ & $3.00( \pm 0.1)$ & $2.50( \pm 0.3)$ & 1.20 \\
$\mathrm{G}$ & $3.00( \pm 0.2)$ & $2.50( \pm 0.2)$ & 1.20 \\
$\mathrm{H}$ & $2.50( \pm 0.1)$ & $2.00( \pm 0.1)$ & 1.25 \\
$\mathrm{I}$ & $2.00( \pm 0.2)$ & $1.50( \pm 0.3)$ & 1.33 \\
$\mathrm{~J}$ & $2.50( \pm 0.1)$ & $2.00( \pm 0.2)$ & 1.25 \\
K & $2.00( \pm 0.3)$ & $1.40( \pm 0.2)$ & 1.43 \\
$\mathrm{~L}$ & $2.00( \pm 0.1)$ & $1.40( \pm 0.2)$ & 1.43 \\
M & $2.00( \pm 0.2)$ & $1.80( \pm 0.2)$ & 1.11 \\
$\mathrm{~N}$ & $2.00( \pm 0.1)$ & $1.80( \pm 0.1)$ & 1.11 \\
O & $2.00( \pm 0.4)$ & $1.50( \pm 0.1)$ & 1.33 \\
P & $2.50( \pm 0.2)$ & $2.00( \pm 0.1)$ & 1.25 \\
Q & $2.00( \pm 0.1)$ & $1.60( \pm 0.2)$ & 1.25 \\
R & $1.80( \pm 0.1)$ & $1.40( \pm 0.2)$ & 1.28 \\
S & $2.50( \pm 0.2)$ & $2.00( \pm 0.3)$ & 1.25 \\
T & $2.50( \pm 0.3)$ & $2.00( \pm 0.3)$ & 1.25 \\
Mean $( \pm)$ & $2.38(0.46)$ & $1.94(0.44)$ & $1.24(0.096)$ \\
\hline Kruskal- & 123.562 & 54.353 & \\
Wallis $(\mathrm{H})$ & $\mathrm{p}=0.000$ & $\mathrm{p}=0.000$ & \\
\hline & & &
\end{tabular}

The result of each lot of vaccine represents the mean \pm SD from 7 repeated experiments for the toxin binding inhibition (ToBI) test and 3 repeated experiments for the in vivo test. The KruskalWallis test among repetitions for ToBI test was $\mathrm{H}=1.367(\mathrm{p}=$ $0.968)$ and for the in vivo test was $H=0.232(p=0.891)$. These results are not significantly different. The results inter lots are significantly different.
TABLE II

Tetanus component potency of diphtheria-tetanus-pertussis vaccine by in vitro and in vivo neutralization tests

\begin{tabular}{lccc}
\hline Vaccine & \multicolumn{2}{c}{$\begin{array}{c}\text { Tetanus antitoxin } \\
\text { (IU/ml) }\end{array}$} & $\begin{array}{c}\text { Ratio } \\
\text { in vitro/in vivo }\end{array}$ \\
\cline { 2 - 4 } Lots & ToBI & L $+/ 10 / 50$ & ToBI/in vivo \\
\hline A & $3.20( \pm 0.2)$ & $2.80( \pm 0.2)$ & 1.14 \\
B & $2.50( \pm 0.1)$ & $2.25( \pm 0.2)$ & 1.11 \\
C & $3.00( \pm 0.3)$ & $2.60( \pm 0.1)$ & 1.15 \\
D & $2.00( \pm 0.1)$ & $1.80( \pm 0.2)$ & 1.11 \\
E & $3.50( \pm 0.4)$ & $3.00( \pm 0.1)$ & 1.17 \\
F & $3.00( \pm 0.2)$ & $2.50( \pm 0.3)$ & 1.20 \\
G & $2.50( \pm 0.1)$ & $2.00( \pm 0.1)$ & 1.25 \\
H & $2.00( \pm 0.1)$ & $2.00( \pm 0.2)$ & 1.00 \\
I & $2.00( \pm 0.1)$ & $2.00( \pm 0.2)$ & 1.00 \\
J & $4.00( \pm 0.4)$ & $3.50( \pm 0.1)$ & 1.14 \\
K & $2.50( \pm 0.3)$ & $2.00( \pm 0.3)$ & 1.25 \\
L & $2.80( \pm 0.1)$ & $2.60( \pm 0.1)$ & 1.08 \\
M & $2.00( \pm 0.2)$ & $1.80( \pm 0.4)$ & 1.11 \\
N & $3.50( \pm 0.1)$ & $3.00( \pm 0.1)$ & 1.17 \\
O & $3.00( \pm 0.2)$ & $2.50( \pm 0.2)$ & 1.20 \\
P & $2.50( \pm 0.1)$ & $2.00( \pm 0.1)$ & 1.25 \\
Q & $3.00( \pm 0.2)$ & $2.60( \pm 0.3)$ & 1.15 \\
R & $2.00( \pm 0.1)$ & $1.80( \pm 0.1)$ & 1.11 \\
S & $2.00( \pm 0.2)$ & $1.80( \pm 0.2)$ & 1.11 \\
T & $2.50( \pm 0.3)$ & $2.10( \pm 0.1)$ & 1.19 \\
Mean $( \pm)$ & $2.68(0.59)$ & $2.33(0.49)$ & $1.14(0.07)$ \\
\hline Kruskal- & 130.072 & 53.814 & \\
Wallis $(H)$ & $\mathrm{p}=0.000$ & $\mathrm{p}=0.000$ & \\
\hline & & &
\end{tabular}

The result of each lot of vaccine represents the mean \pm SD from 7 repeated experiments for the toxin binding inhibition (ToBI) and 3 repeated experiments for the in vivo test. The KruskalWallis test among repetitions was $\mathrm{H}=0.487(\mathrm{p}=0.998)$ for the ToBI test and $\mathrm{H}=1.133(\mathrm{p}=0.567)$ for the in vivo test. These values are not statistically different. The results inter lots are statistically different.

( $\mathrm{p}=0.891)$ for $\mathrm{dT}$ and $\mathrm{H}=1.133(\mathrm{p}=0.567)$ for DTP. However, a high heterogeneity of results was observed among the lots for both vaccines, by ToBI as well as by TN in mice.

Fig. 2 shows the distribution of tetanus antitoxin levels obtained by ToBI and in vivo neutralization tests for all lots of dT and DTP analyzed. The Spearman's correlation coefficient was also calculated demonstrating an excellent correlation of these tests for each lot of dT ( $\mathrm{r}=$ 0.940 and $p=0.000)$ and DTP $(r=0.951$ and $p=0.000)$ studied.

\section{DISCUSSION}

The principle of the ToBI test is related to the in vivo $\mathrm{TN}$ test procedure and is based on the detection of free toxin in toxin-serum mixtures, using an ELISA instead of live animals. The only difference between the ToBI test and the in vivo TN test is the way in which the free toxin is assayed, e. g. by ELISA or in a mouse assay (Hendriksen et al. 1989a).

Butantan Institute is the major Brazilian manufacturer of bacterial adsorbed vaccines since 1967 and supplies in part the National Program of Immunization organized by 


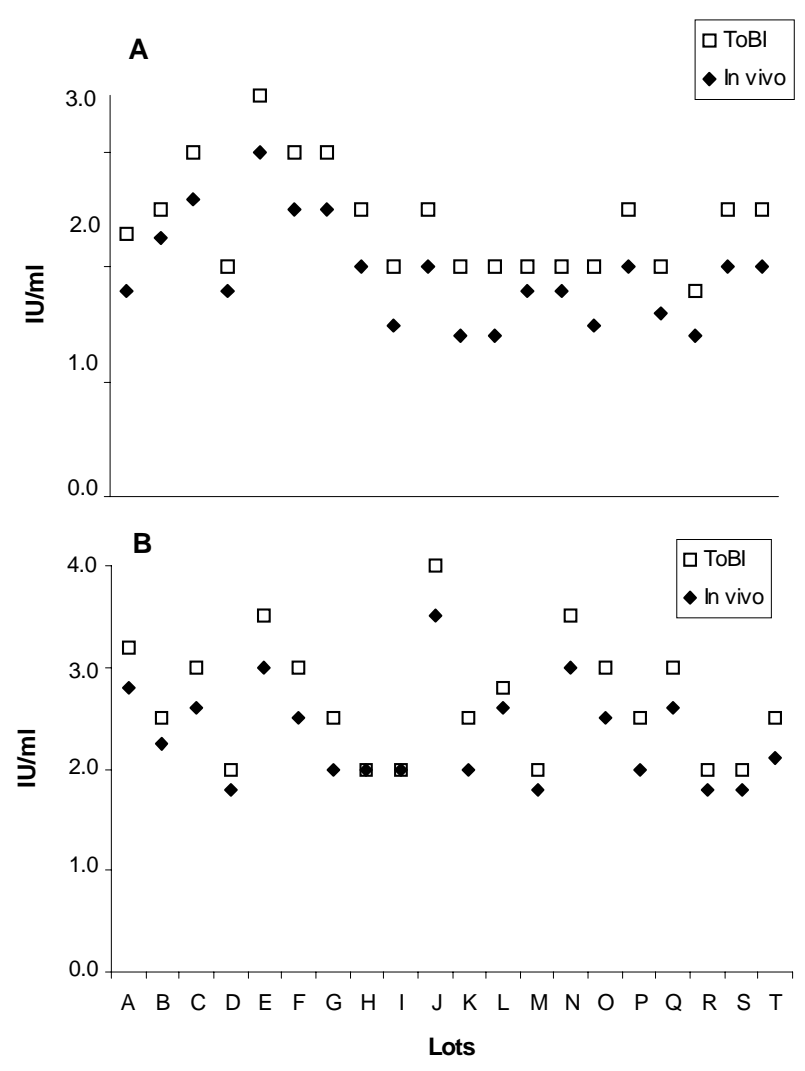

Fig. 2: distribution of tetanus antitoxin levels obtained by in vivo and in vitro tests per lot. Spearman's correlation coefficient between in vivo and in vitro results (Tables I and II) demonstrated $\mathrm{r}=$ $0.940(\mathrm{p}=0.000)$ for the diphteria-tetanus vaccine and $\mathrm{r}=0.951$ $(\mathrm{p}=0.000)$ for the diphiteria-tetanus-pertussis vaccine. ToBI: toxin binding inhibition

Brazilian Ministery of Health. Although this Institute has good conditions for animal facilities, the current protocols for biological control for in-process and final production of vaccines are expensive, toilsome and the release of final results requires several days. Its production of dT and DTP vaccines shows an excellent consistence of the quality of vaccine produced. In this context, the set of results presented herein and analyzed statistically prove that the ToBI test is precise and reproducible when compared with the in vivo TN test currently used. Other authors also have related that this in vitro test demonstrates to be specific, sensitive, reproducible and the results less variable in relation to in vivo TN tests in mice (Hendriksen et al. 1988, 1991).

The ToBI test has been successfully used to determine diphtheria antitoxin in human and animal sera (Hendriksen et al. 1989b, Hong \& Hendriks 1999, Marcovistz et al. 2002).

The essential difference between the ToBI test developed by Hendriksen et al. (1988) and that standardized by us was the use of tetanus anatoxin instead of tetanus toxin. This was possible because the detoxification of the toxin does not modify its antigenic epitopes and can be handled without risk of health for the staff.
The results obtained by ToBI test were very similar to the results obtained using the in vivo TN test. The arithmetic means of in vitro/in vivo ratio obtained by ToBI and $\mathrm{TN}$ in mice for both vaccines have shown good correspondence. The Kruskal-Wallis test showed high homogeneity between the ToBI test and the TN in mice among the results for each lot of vaccine analyzed. The heterogeneity of results among the lots studied could, at least in part, be due to the individual ability of guinea pigs to respond to the vaccine inoculation, but also by some difference in the concentration of components during vaccine formulation. Hendriksen et al. (1989a) also reported a significant correlation of these methods assaying tetanus and diphtheria antitoxin in human sera.

Apart from the similarity of results found by in vitro and in vivo tests, the ToBI test offers distinct advantages in relationship to $\mathrm{TN}$ in mice such as: the use of anatoxin instead of toxin, no requirement of a large number of animals, its ease to perform and the immediacy of results.

Our results lead to the conclusion that the substitution of the in vivo TN test by the ToBI test is pertinacious for assaying tetanus immunogenicity in the quality control of dT and DTP vaccine production.

These results will contribute to the establishment of alternative and more refined tests for the quality control of adsorbed vaccines by the National Control Authorities in Brazil. Further, they can also stimulate other manufacturers from developing countries to perform in vitro tests for the quality control of their vaccine production. Thus, leading amplify the network of knowledge to replacement, reduction and refinement, the so-called 3Rs (Sesardic \& Hendriksen 1999), of animals in control of biological products.

\section{REFERENCES}

Avrameas S, Ternynck T 1971. Peroxidase labeled antibody and Fab conjugates with enhanced intracellular penetration. Immunochemistry 8: 1175-1179.

Esparza I, Kissel T 1992. Parameters affecting the immunogenicity of microencapsulated tetanus toxoid. Vaccine 10:714720.

Farmacopéia Brasileira 2000. 4a. ed., Parte II, $2^{\circ}$ fasc., Atheneu, São Paulo.

Gentili G, Pini C, Collotti C 1985. The use of an immunoenzymatic assay for the estimation of tetanus antitoxin in human sera: a comparison with seroneutralization and indirect haemagglutination. J Biol Stand 13: 53-59.

Gupta RK, Siber GR 1994. Comparative analysis of tetanus antitoxin titers of sera from immunized mice and guinea pigs determined by toxin neutralization test and enzymeliked immunosorbent assay. Biologicals 22: 215-219.

Gupta RK, Maheshwari SC, Singh H 1984. The titration of tetanus antitoxin III. A comparative evaluation of indirect haemagglutination and toxin neutralization titres of human sera. J Biol Stand 12: 145-149.

Hendriksen CFM, Gun JW van der, Kreeftenberg JG 1989a. Combined estimation of tetanus and diphtheria antitoxin in human sera by the in vitro toxin-binding inhibition (ToBI) test. J Biol Stand 17: 191-200.

Hendriksen CFM, Gun JW van der, Kreeftenberg JG 1989b. The use of toxin binding inhibition (ToBI) test for the estimation of the potency of the diphtheria component of vaccines. J Biol Stand 17: 241-247. 
Hendriksen, CFM, Gun JW van der, Marsman, FR, Kreeftenberg JG 1991. The use of the in vitro toxin binding inhibition (ToBI) test for the estimation of the potency of tetanus toxoid. Biologicals 19: 23-29.

Hendriksen CFM, Gun JW van der, Nagel J, Kreeftenberg JG 1988. The toxin binding inhibition test as a reliable in vitro alternative to the toxin neutralization test in mice or the estimation of tetanus antitoxin in human sera. J Biol Stand 16: 287-297.

Hong HA, Hendriks J 1999. The use of alternatives to animals tests in developing countries. In F Brown, CFM Hendriksen, D Sesardic (eds), Alternatives to Animals in the Development and Control of Biologicals Products for Human and Veterinary Use, Vol. 110, Dev. Biol. Stand. Basel, Karger, p. 209-214.

Huet M, Relyveld E, Camps S 1992. Simplified activity evaluation of several tetanus vaccines. Biologicals 20: 35-43.

Marcovistz R, Matos DCS, Georgini RA, Sakauchi D 2002. Potency control of diphtheria component in adsorbed vaccines by in vitro neutralization tests. Biologicals 29 in press
Melville-Smith ME, Seagroatt VA, Watkins JT 1983. A comparison of enzyme-linked immunosorbent assay (ELISA) with the toxin neutralization test in mice as a method for estimation of tetanus antitoxin in human sera. J Biol Stand 11: 137-144.

Secretaria de Vigilância Sanitária 1998. Portaria no. 551. Normas de Produção e Controle da Vacina Tríplice (DTP). Centro de Documentação do Ministério da Saúde, Brasília, Brasil.

Peel MM 1980. Measurement of tetanus antitoxin I. Indirect haemagglutination. J Biol Stand 8: 177-189.

Sesardic D, Hendriksen CFM 1999. Alternatives to animals in the development and control of biological products for human and veterinary use. Biologicals 27: 55-57.

Simonsen O, Schou C, Heron I 1987. Modification of the ELISA for the estimation of tetanus antitoxin in human sera. $J$ Biol Stand 15: 143-157.

Statistical Package of Social Sciences - SPSS software, version 8.0, 1997. SPSS Inc., Chicago, Illinois.

WHO-World Health Organization 1995. Manual of laboratory methods for potency testing of vaccine used in the WHO Expanded Program on Immunization: introduction to potency control of bacterial vaccines, WHO, Geneve. 
914 Tetanus Immunogenicity - Denise Cristina Souza M atos et al. 